\title{
Effects of Glyphosate-, Glufosinate- and Flazasulfuron-Based Herbicides on Soil Microorganisms in a Vineyard
}

\author{
Karin Mandl ${ }^{1} \cdot$ Clemens Cantelmo $^{1,2} \cdot$ Edith Gruber $^{2} \cdot$ Florian Faber $^{1} \cdot$ Barbara Friedrich $^{1} \cdot$ Johann G. Zaller $^{2}$
}

Received: 15 May 2018 / Accepted: 3 September 2018 / Published online: 18 September 2018

(C) The Author(s) 2018

\begin{abstract}
In a vineyard we examined the effects of broad-spectrum herbicides with three different active ingredients (glyphosate, glufosinate, flazasulfuron) on soil microorganisms. Mechanical weeding served as control treatment. Treatments were applied within grapevine rows and soil samples taken from there in 10-20 cm depth 77 days after application. Fungi were analyzed using classical sequencing technology and bacteria using next-generation sequencing. The number of colony-forming units (CFU) comprising bacteria, yeasts and molds was higher under flazasulfuron compared to all other treatments which had similar CFU levels. Abundance of the fungus Mucor was higher under flazasulfuron than glufosinate and mechanical weeding; Mucor was absent under glyphosate. Several other fungi taxa were exclusively found under a specific treatment. Up to 160 different bacteria species were found - some of them for the first time in vineyard soils. Total bacterial counts under herbicides were on average $260 \%$ higher than under mechanical weeding; however due to high variability this was not statistically significant. We suggest that herbicide-induced alterations of soil microorganisms could have knock-on effects on other parts of the grapevine system.
\end{abstract}

Keywords Soil biota $\cdot$ Soil microbes $\cdot$ Non-target effects $\cdot$ Pesticide $\cdot$ Viticulture $\cdot$ Weed control

With an increasing intensification of viticulture, chemical weed control within and between grapevine rows is more widely used (Keller 2015). Weeds compete with vines for water and nutrients and herbicides are used to avoid trunk damage caused by mechanical weeding machinery and to reduce working time spent in the vineyard. Among the most often used herbicides in vineyards are those based on the active ingredients glyphosate, glufosinate and flazasulfuron (Bauer et al. 2017). While effects on soil organisms of fungicides and/or insecticides have been reported from vineyards (Paoletti et al. 1998), very little is known on the impacts of herbicides (Zaller et al. 2018). Moreover, laboratory and pot studies showed various non-target effects of herbicides on

Johann G. Zaller

johann.zaller@boku.ac.at

$1 \quad$ Federal College and Research Center for Viticulture and Pomology, Wienerstraße 74, 3400 Klosterneuburg, Austria

2 Institute of Zoology, University of Natural Resources and Life Sciences, Vienna, Gregor-Mendel-Straße 33, 1180 Vienna, Austria soil microbial communities (van Hoesel et al. 2017; Wilkinson and Lucas 1969; Zaller et al. 2014).

Weed control measures can affect soil microorganisms either by eliminating weeds and their associated rhizosphere or by directly influencing the physiology and diversity of microorganisms (Carson et al. 2007; Corneo et al. 2013; Marilley and Aragno 1999). Studies are mainly concerned with bacterial communities; the few that studied fungi focused mainly on arbuscular mycorrhizal symbiosis in arable fields (Rillig 2004). Only a few studies investigated soil microbial communities in vineyards (Fernández-Calviño et al. 2010; Likar et al. 2017; Samad et al. 2017; Steenwerth et al. 2008; Zaller et al. 2018). A study reports significant different microbiomes between grapevines roots and rhizosphere and weeds (Samad et al. 2017).

For healthy and fertile vineyard soils, a diverse population of microorganisms is essential for plant health, plant growth and productivity (Chaparro et al. 2012; Zarraonaindia et al. 2015). Knowledge of interactions between microorganisms in the soil, the rhizosphere and the phyllosphere is increasing (Pinto and Gomes 2016). Bacterial communities on the grapes have been shown to influence the organoleptic properties of the wine, what contributes to a regional 
terroir (Mezzasalma et al. 2017). Additionally, management practices as well as ecological and environmental factors influence soil microbiota (Pancher et al. 2012; Zehetner et al. 2015), thereby affecting the characteristics of the wine (Zarraonaindia et al. 2015).

The objective of the current study was to examine potential effects on soil microorganisms of three commonly used herbicides in comparison to mechanical weeding. The three herbicides differed in their mode-of-action. Herbicide one contained the active ingredient glyphosate that acts on the 5-enolpyruvylshikimate-3-phosphate (EPSP) synthase in plants (Steinrücken and Amrhein 1980). Herbicide two contained glufosinate that acts on glutamine synthetase (Duke 2014). Herbicide three was based on flazasulfuron that inhibits the amino acid synthesis, cell division and ultimately plant growth (Magné et al. 2006). Studies on herbicide effects on soil microbial communities can help developing more sustainable weed control measures for vineyard management.

\section{Materials and Methods}

The study was conducted in 2016 in an experimental vineyard (Rothäcker XV) of the Federal College and Research Center for Viticulture and Pomology, in Klosterneuburg, near Vienna, Austria (coordinates $48.294809^{\circ} \mathrm{N}$, $16.324693^{\circ} \mathrm{E} ; 192 \mathrm{~m}$ above sea level). The vineyard consisted of 22, on average $30 \mathrm{~m}$ long vineyard rows and was established in 2011 with the white grape variety Gewürztraminer (Vitis vinifera L.) using trellis (grapevine withinrow distance: $1.0 \mathrm{~m}$; row distance: $2.8 \mathrm{~m}$ ). The area is southfacing, slightly inclined and the inter-rows were cultivated according to the Austrian soil erosion prevention programme allowing only tillage of every second inter-row, while leaving the other rows uncultivated and vegetated (ÖPUL 2007). The vineyard was organically fertilised once (23 March 2016, $61 \mathrm{~kg} \mathrm{~N} / \mathrm{ha}$; product BioAgenasol, Agrana, Austria); plant protection measures were applied evenly across the vineyard following good viticultural practice (Table 1). Soils at the study site developed from alluvial soils of sandy, brown primary material and rounded pebble stones; additionally, chiselled Flysch marl stemmed from colluvial processes.

We selected two rows for each herbicide treatment. Each herbicide treatment covered the undergrowth of five grapevines at a width of $0.5 \mathrm{~m}$; a distance of two untreated grapevines was left between herbicide applications. Between herbicide treated rows two rows were left untreated to avoid cross-contamination.

We used four different treatments for weed control within grapevine rows: three broadband herbicides with different active ingredients and mechanical weeding as a control. All herbicides were applied according to good farming practice at the recommended dosage. Roundup PowerFlex (Monsanto Agrar Deutschland, Düsseldorf, Germany) with the active ingredient glyphosate as potassium salt $(200 \mathrm{~g} / \mathrm{L})$ was applied in a concentration of $3.75 \mathrm{~L} / \mathrm{ha}$. Basta $150 \mathrm{SL}$
Table 1 Plant protection applied additionally to the weed control treatments in the study vineyard during the course of the experiment. Soil samples were taken on 23 June 2016

\begin{tabular}{|c|c|c|c|c|}
\hline Date 2016 & Pest/disease & Product & Dosage & Manufacturer \\
\hline 13 April & Grape leaf rust mites & Thiovit Netzschwefel & $3.0 \mathrm{~kg} / \mathrm{ha}$ & Syngenta Agro \\
\hline \multirow[t]{4}{*}{22 April } & Powdery mildew & Thiovit Netzschwefel & $2.0 \mathrm{~kg} / \mathrm{ha}$ & Syngenta Agro \\
\hline & & Vivando & $0.15 \mathrm{~L} / \mathrm{ha}$ & BASF SE \\
\hline & Downy mildew & Polyram WG & $0.8 \mathrm{~kg} / \mathrm{ha}$ & BASF SE \\
\hline & $\begin{array}{l}\text { Grape black rot } \\
\text { Dead arm }\end{array}$ & & & \\
\hline \multirow[t]{5}{*}{9 May } & Powdery mildew & Thiovit Netzschwefel & $2.0 \mathrm{~kg} / \mathrm{ha}$ & Syngenta Agro \\
\hline & & Vegas & $0.25 \mathrm{~L} / \mathrm{ha}$ & Nisso Chemical Eur \\
\hline & Downy mildew & Polyram WG & $0.8 \mathrm{~kg} / \mathrm{ha}$ & BASF SE \\
\hline & Grape black rot & & & \\
\hline & Dead arm & & & \\
\hline \multirow[t]{5}{*}{1 June } & Powdery mildew & Thiovit Netzschwefel & $2.0 \mathrm{~kg} / \mathrm{ha}$ & Syngenta Agro \\
\hline & & Flint max & $0.18 \mathrm{~kg} / \mathrm{ha}$ & Bayer Crop Science \\
\hline & Downy mildew & Dithane Neo Tec & $2.0 \mathrm{~kg} / \mathrm{ha}$ & Star Agro \\
\hline & Rotbrenner disease & & & \\
\hline & Dead arm & & & \\
\hline \multirow[t]{4}{*}{18 June } & Powdery mildew & Thiovit Netzschwefel & $2.0 \mathrm{~kg} / \mathrm{ha}$ & Syngenta Agro \\
\hline & & Vegas & $0.5 \mathrm{~L} / \mathrm{ha}$ & Nisso Chemical Eur \\
\hline & Downy mildew & Aktuan gold & $1.56 \mathrm{~kg} / \mathrm{ha}$ & BASF SE \\
\hline & & Cuprofor flow & $1.0 \mathrm{~L} / \mathrm{ha}$ & Kwizda Agro \\
\hline
\end{tabular}


(Bayer CropScience Austria, Vienna, Austria) based on glufosinate-ammonium was applied at 5.0 L/ha. Katana (ISK Biosciences Europe, Brussels, Belgium) based on flazasulfuron was applied at $200 \mathrm{~g} / \mathrm{ha}$.

Herbicides were applied by an experienced viticultural technician early in the morning with a backpack sprayer on 7 April 2016 first at a temperature of $12^{\circ} \mathrm{C}$ under calm conditions. Mechanical weeding was also performed on 7 April 2016 using a hand weeding tool; no herbicides were applied between rows. As recommended by the manufacturer, Basta was applied a second time (7 June 2016). Vegetation height at the time of weed control applications was about $20 \mathrm{~cm}$.

Two bulk soil samples per treatment replicate were taken on 23 June 2016 ( 77 days after the first herbicide application) from the middle of the treated rows in $20 \mathrm{~cm}$ distance to the grapevine at $10-20 \mathrm{~cm}$ depth using a quadratic soil corer $(5 \times 5 \times 10 \mathrm{~m}$, length $\times$ width $\times$ depth $)$.

For determination of microbial counts and identifying the microorganisms $1 \mathrm{~g}$ of each soil sample was randomly selected and used for a dilution series. As nutrient solution three different agar plates were used, Malt Extract Agar MEA (Weidenbörner 1998), Wallerstein Laboratory WL and Tryptic Soy Agar TSA (Carl Roth GmbH, Karlsruhe, Germany). After 6 days of incubation at $24^{\circ} \mathrm{C}$ the microbial colonies were assessed by visually differentiating bacteria, yeasts and molds.

Yeasts were purely cultivated on MEA agar and cultivated in Malt Extract bouillon for 4-7 days. Then yeasts were reamed with a mortar and purified with a MasterPureTMPurification Kit (MCD85201 Epicentre, Illumina Company, USA). Afterwards an ITS1-ITS4 PCR (White et al. 1990) was performed. Bacteria were purely cultivated on PC agar and cultivated overnight in Standard I nutrient bouillon (art. 1.07882.0500, Merck, Darmstadt, Germany). DNA purification was carried out with MasterPureTM - purification kit (MCD85201 Epicentre, Illumina Company, USA) followed by a PCR with AC1 and AC3 primer (Poblet et al. 2000).

For gel band purification a WizardSV Gel and PCR Clean-Up System (A 9281, Promega, USA) was used. Sequencing was performed by an external laboratory (Eurofins Genomics GmbH, Ebersberg, Germany). DNA results were analysed using the database of the US National Center for Biotechnology Information (https://www.ncbi.nlm.nih. gov/).

From the same soil samples, about $400 \mathrm{~g}$ of fresh soil was sent to a commercial laboratory (Eurofins Genomics, Ebersberg, Germany) in order to perform next-generation sequencing (NGS). The DNA-extraction was performed using a NucleoSpin soil kit (Macherey Nagel, Düren, Germany). Analyses were made with an Illumina MiSeq v3, $2 \times 300$ bp Modus. For the target region V1V3 the primers V1V3_F: AGAGTTTGATCATGGCTCAG and V1V3_R: GTATTACCGCGGCTGCTG were used. The applied
PCR program involved 2 min $95^{\circ} \mathrm{C}$, then 28 cycles $(30 \mathrm{~s}$ $95^{\circ} \mathrm{C}+50 \mathrm{~s} 50^{\circ} \mathrm{C}+1 \min 72^{\circ} \mathrm{C}$ ), then $6 \min 72^{\circ} \mathrm{C}$ and finally $4^{\circ} \mathrm{C}$. The genetical sequences were attached to the associated $16 \mathrm{~S}$ region. The taxonomic comparison was done with the software QIIME (version 1.8.0, http://qiime.org) and the NCBI database. After preprocessing and quality filtering 2,408,208 16S-gen sequences with a range from 127,194 to 566,193 sequences per sample were gained. Diversity of microbial communities from NGS data were analysed by calculating Shannon diversity and evenness indices on the taxonomic categories phyllum, class, order, family, genus and species.

Prior to the microbiome analysis, raw reads were demultiplexed/debarcoded based on the unique forward and reverse sequencing indices and/or inline-barcode sequences. To preserve only high-quality reads, all reads with sequencing errors or reads with ambiguous bases ("N") were removed. Indices/barcodes as well as primer sequences were clipped from the reads. The remaining set of high-quality reads was processed using minimum entropy decomposition (Eren et al. 2015). Minimum entropy decomposition (MED) provides a computationally efficient means to partition marker gene datasets into OTUs (Operational Taxonomic Units). Each OTU represents a distinct cluster with significant sequence divergence to any other cluster. By employing Shannon entropy, MED uses only the information-rich nucleotide positions across reads and iteratively partitions large datasets while omitting stochastic variation. The MED procedure outperforms classical, identity-based clustering algorithms. Sequences can be partitioned based on relevant single nucleotide differences without being susceptible to random sequencing errors. This allows a decomposition of sequence data sets with a single nucleotide resolution. Furthermore, the MED procedure identifies and filters random "noise" in the dataset. This includes singletons and putative chimeric sequences. To assign taxonomic information to each OTU, BLAST alignments of cluster representative sequences to the NCBI sequence database were performed. A most specific taxonomic assignment for each OTU was then transferred from the set of best-matching reference sequences. Hereby, a sequence identity of $80 \%$ across at least $80 \%$ of the representative sequence was a minimal requirement for considering reference sequences. Further processing of OTUs and taxonomic assignments was performed using the QIIME software package (version 1.8.0, http:// qiime.org/). Abundances of bacteria and archaea taxonomic units were normalized using lineage-specific copy numbers of the relevant marker genes to improve estimates (Angly et al. 2014). Results of read preprocessing, OTU picking, and taxonomic assignment is presented in Table 2.

The number of OTUs correlates with the diversity of the data set. Sequences that were considered as noise by the OTU picking algorithm were not assigned to an OTU. This 
Table 2 Summary of next generation sequencing preprocessing

\begin{tabular}{lrl}
\hline Parameter & \multicolumn{1}{l}{ OTUs } & Percentage \\
\hline Total number of input sequences & $2,411,541$ & 100.0 \\
Remaining sequences after preprocessing & $2,408,208$ & 99.9 \\
$\quad$ and quality filtering & & \\
Total number of sequences assigned to & $1,851,837$ & 76.8 \\
$\quad$ OTUs & & \\
Total number of sequences assigned to taxa & $1,284,409$ & 53.3 \\
Copy-number corrected total count & 685,031 & N/A \\
Total number of OTUs & 6957 & 100.0 \\
Number of OTUs assigned to taxa & 4728 & 68.0 \\
Sequences per sample assigned to OTUs & & \\
Min & 99,429 & \\
Max & 432,715 & \\
Median & 144,058 & \\
Mean & 231,479 & \\
Std. dev. & 145,993 & \\
\hline
\end{tabular}

includes singletons and putative chimeric sequences. The fraction of OTUs that could be assigned to taxa indicates how well the microbiome is represented in the used reference database. A copy-number correction was performed for bacterial species only (Angly et al. 2014). To do so, the number of reads assigned to a species was divided by the known or assumed copy-number of marker genes/regions. After preprocessing, sequences were clipped to $255 \mathrm{bp}$ length to remove low quality bases from the $3^{\prime}$ end and to ensure that all sequences have the same length. The latter is crucial for the MED analysis.

Statistical analysis of CFUs and OTUs were performed using the FASTQ file format (Cock et al. 2010) within the software package R (version 3.0.2, The R Foundation for Statistical Computing 2013). Shannon- and Evenness indices were analysed using one-way analysis of variance (ANOVA) with the factor herbicide treatment (4 levels). Mean comparisons between herbicide treatments were performed using Tukey tests. Differences with $p<0.05$ were considered to be significant.

\section{Results and Discussion}

Weed control significantly affected total CFUs in vineyard soils. Significantly more total CFUs were found under flazasulfuron $\left(24.13 \pm 83.32 \times 10^{6}\right.$, mean $\left.\pm S D\right)$ than under glyphosate $\left(0.27 \pm 0.79 \times 10^{6}\right)$, glufosinate $\left(2.78 \pm 9.32 \times 10^{6}\right)$ or the control treatment $\left(1.56 \pm 5.48 \times 10^{6}\right.$; Fig. 1$)$. Weed control treatments had no significant effect on the proportion of yeasts, molds and bacteria in soil samples (Fig. 1). There was a trend for considerably more molds and yeasts but less bacteria under flazasulfuron than under the other treatments,

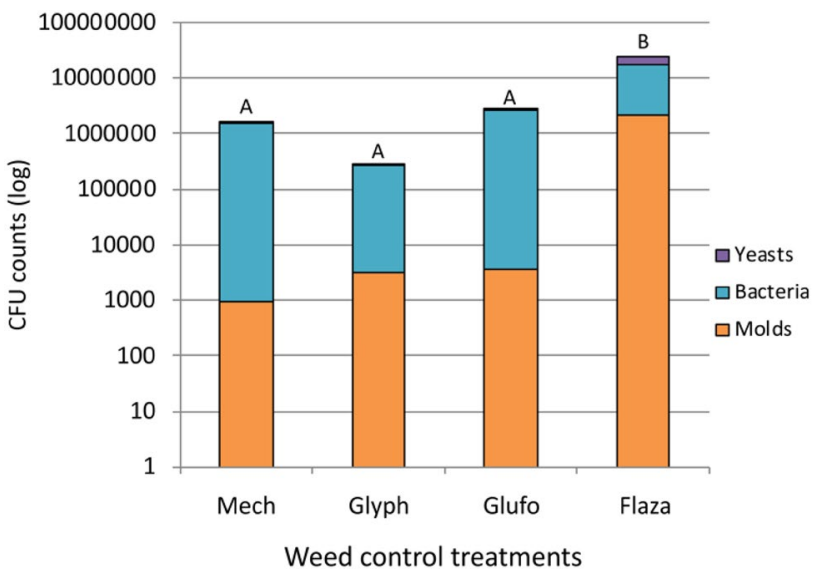

Fig. 1 Mean proportions of yeasts, bacteria and molds in soil samples in vineyards rows after mechanical weeding (mech) or three herbicide treatments (glyph...glyphosate, glufo...glufosinate, flaza...flazasulfuron). Different letters denote significant differences of the total CFU counts (Tukey HSD, $p<0.05$ ). Data obtained by classical sequencing

however due to high heterogeneity this was not statistically significant. Such unclear patterns of herbicide effects on the microbial soil communities have also been reported by others (Kopčáková et al. 2016; Newman et al. 2016). However, a clear difference in soil bacterial and fungal composition in vineyards was reported between herbicide treated and untreated grapevine rows (Chou et al. 2018; Hendgen et al. 2018).

NGS analyses showed that abundances of cultivable and not-cultivable soil bacteria under herbicide treatments were on average $264 \%$ higher than under mechanical weeding (Fig. 2). However, due to high data variability this was not statistically significant. Across treatments we found strains of the following taxa with decreasing abundances: Proteobacteria $(35.8 \% \pm 3.6 \%$, mean \pm SD across treatments), Actinobacteria $(13.0 \% \pm 2.4 \%)$, Gemmatimonadetes $(5.5 \% \pm 1.0 \%)$, Acidobacteria $(3.5 \% \pm 0.5 \%)$, Nitrospira $(3.4 \% \pm 0.9 \%)$, Bacterioidetes $(3.1 \% \pm 0.6 \%)$, Ignavibacteriae $(2 \% \pm 0.1 \%)$, Plantomycetes $(1.7 \% \pm 0.3 \%)$, Firmicutes $(1.2 \% \pm 0.2 \%)$, Chloroflexi $(1.0 \% \pm 0.2 \%)$, Verrucomicrobia $(0.9 \% \pm 0.3 \%)$, Cyanobacteria $(0.2 \% \pm 0.1 \%)$, Armatimonadetes $(0.1 \% \pm 0.1 \%)$, Synergistes $(0.005 \% \pm 0.003 \%)$, Tenericutes $(0.003 \% \pm 0.003 \%)$, Thermodesulfobacteria $(0.02 \% \pm 0.02 \%)$ and unclassified strains $(30.6 \% \pm 2.3 \%)$.

Considering individual fungal taxa, only the abundance of Mucor was significantly affected by herbicide treatments (Fig. 3a). Mucor was absent under glyphosate and highest under flazasulfuron with similar CFUs under mechanical weeding and glufosinate (Fig. 3a). Mucor spp. are very common mainly in organic plant material like compost, fruits or vegetable, wood pellets and farmyard manure and are known to cause food spoilage (Domsch et al. 2007; Hoog et al. 2000). Mucor has been detected in air samples in 


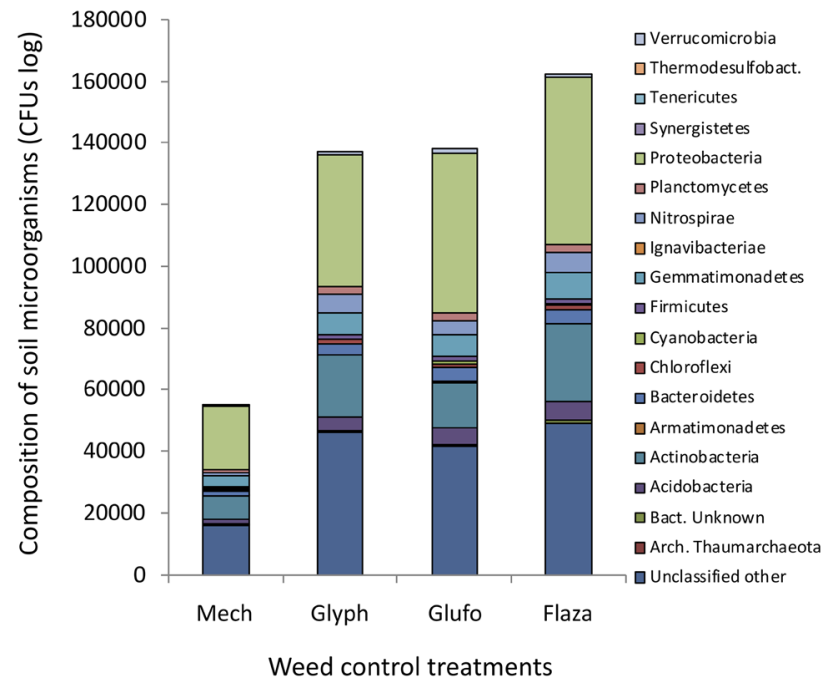

Fig. 2 Composition of soil bacteria and archeobacteria communities in vineyards rows after mechanical weeding (mech) and three herbicide treatments (glyph...glyphosate, glufo...glufosinate, flaza...flazasulfuron). Data obtained by NGS sequencing
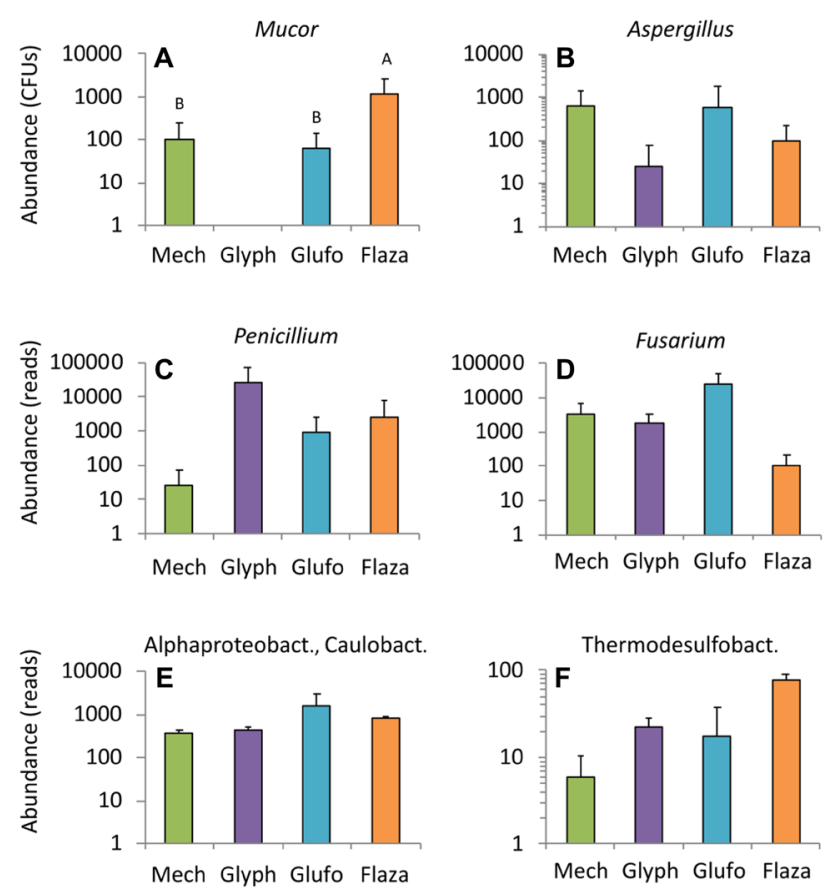

Weed control treatment

Fig. 3 Selected taxa of soil microorganisms in vineyards rows under mechanical weeding (mech) and application of three herbicide (glyph...glyphosate, glufo...glufosinate, flaza...flazasulfuron). Means \pm SD. Different letters denote significant differences (Tukey HSD, $p<0.05)$. Fungi data obtained using classical sequencing, bacteria data by NGS sequencing
Italian vineyards (Magyar et al. 2009), in grape berries in the Tokaj wine region in Hungary (Felšöciová et al. 2015) and is described as a pathogenic fungus on pear fruits (Mari et al. 2000). To the best of our knowledge the current study is among the first describing Mucor from vineyard soil samples below $10 \mathrm{~cm}$ depth.

The ubiquitous Aspergillus sp., Penicillium sp. and Fusarium sp. were detected in all treatments with high variability (Fig. 3b-d; Table 3), however no significant effect of weed control was seen. Alphaproteobacteriaceae and Caulobacteriaceae were observed in all samples but with little variation among treatments (Fig. 3c). Presence of Caulobacterales (Fig. 3e) have been described in the Chardonnay and Merlot varieties (Campisano et al. 2014; Pinto and Gomes 2016) and in grapevine roots (Samad et al. 2017) and in association with copper (Andreazza et al. 2012). In the current study there was a not-significant trends of $1 \%-37 \%$ higher reads of Caulobacter under herbicides than under mechanical weeding. Also, Thermosulfobacteria showed a not-significant trend to $9 \%-58 \%$ higher reads under herbicide treatments than under mechanical weeding (Fig. 3f). Thermodesulfobacteria are sulfate-reducing usually found in hot springs (Meyer-Dombard and Amend 2014; Wang et al. 2013) and were described after treatment with Autographa californica multiple nucleopolyhedovirus (Fu et al. 2015) or after biochar application (Abujabhah et al. 2017).

Table 3 Presence (+) or absence (-) of particular fungi taxa in soil samples under mechanical weeding (mech) and application of three herbicides (glyph...glyphosate, glufo...glufosinate, flaza...flazasulfuron)

\begin{tabular}{lcccc}
\hline Fungi taxa & Mech & Glyph & Glufo & Flaza \\
\hline Acremonium sp. & - & - & + & - \\
Arthroderma sp. & - & - & - & + \\
Aspergillus sp. & + & + & + & + \\
Cladosporium sp. & - & + & + & - \\
Clonostachys rosea & + & - & - & - \\
Colletotrichum sp. & - & + & - & - \\
Cunninghamella sp. & - & + & - & - \\
Dipodascus sp. & + & - & - & - \\
Fusarium sp. & + & + & + & + \\
Gongronella butleri & - & - & + & - \\
Mortierella sp. & - & + & - & - \\
Mucor sp. & + & - & + & + \\
Paecilomyces marquandi & - & - & + & - \\
Penicillium sp. & + & + & + & + \\
Scedosporium sp. & - & + & - & - \\
Sporothrix sp. & - & - & + & - \\
Striatibotrys sp. & - & + & - & + \\
Trichoderma sp. & + & + & - & - \\
\hline
\end{tabular}

Taxa in alphabetical order 
Changes in bacterial reads were reported in the rhizosphere of glyphosate-tolerant of corn (Zea mays) and soybean (Glycine max) in response to glyphosate treatment (Newman et al. 2016).

Many fungi described in the current study are reported from vineyard soils for the first time, mainly because of the use of modern sequencing methods (Morgan et al. 2017; Wei et al. 2018). Several taxa were also found specifically under certain treatments. Thus, for the sake of clarity we present an overview of presence/absence data of soil microorganisms found in different weed control treatments (Table 3). However, given the fact that our study only covers one field season in one experimental vineyard we decided for a cautious interpretation of the findings. Overall, it has to be noted that there is a great lack of knowledge on specific functions for most taxa in soil. More long-term studies are needed to assure the generality of our findings.

Under mechanical weeding only the yeast species Clonostachys rosea and the saprophytic fungi Diapodascus sp. were found while they were absent under herbicide treatments (Table 3). Clonostachys rosea is widespread occurring in the soil and in rotten plants and can suppress spores of botrytis bunch rot (Dong et al. 2004; Morandi et al. 2003) and can be pathogens against yeasts ( $\mathrm{Li}$ et al. 2006; Zhao et al. 2005). Chemical isolates of $C$. rosea also showed a negative effect on the nematodes Caenorhabditis elegans, Panagrellus redivivus, and Bursaphelenchus xylophilus (Zhang et al. 2008). Species of the family Dipodascaceae are saprophytically in the plant sap of trees (e.g., Dipodascus albidus) or are colonizing dead insects (Cannon and Kirk 2007).

Under glyphosate only the fungi Colletotrichum sp., Cunninghamella sp., Mortierella sp. and Scedosporium sp. were found (Table 3), suggesting that herbicide-specific nutrients favors these fungi. Many Colletotrichum species are plant pathogenic and have a mutualistic relationship with their host plant (Rodriguez and Redman 2008). For example Colletotrichum coccodes causes tomato anthracnose on the fruit, black dots on the roots and blemishes on the surface of potatoes (Hughes 1958). Cunninghamella sp. is affected by fertilization and can be suppressed by Stachybotrys sp. (=Striatibotrys sp.) and Trichoderma viride (Domsch et al. 2007). Mortiella sp. is together with Mucor one of the first yeast taxa growing on roots of debilitated plants (Deacon 2005; Salt 1977; Webster 2012).

Under glufosinate only the fungi Acremonium sp., Gongronella butleri, Paecilomyces marquandi and Sporothrix sp. were found (Table 3). The genus Acremonium covers more than 100 species living saprophytically on dead plant material or in the soil. Many species can cause diseases in humans (Domsch et al. 2007; Fincher et al. 1991; Hoog et al. 2000). Gongronella butleri is one of the most important species of the Zygomycetes class also used for industrial production (Bartnicki-Garcia 1968; Tan et al. 1996). Paecilomyces marquandi can be detrimental to nematodes and can cause allergies in humans (Kilama et al. 2007; Mücke and Lemmen 2005). Additionally, it contains leucinostatine having an antimicrobial effect against grampositive bacteria and many fungi (Fukushima et al. 1983a, b). The fungi Sporothrix sp. can be found in the soil and on decomposing plant material and can induce infections in humans and animals (Barros et al. 2011; de Meyer et al. 2008; Vasquez-del-Mercado et al. 2012).

Under flazasulfuron only the yeast Arthroderma sp. were exclusively found (Table 3 ). Not much is known about the role of Arthroderma in ecological systems, however it may cause skin problems in humans (Hiernickel et al. 2016).

Several taxa were found under more than one treatment (Table 3). Species of the genus Cladosporium are very common and mainly occur in the soil and on plants, we found Cladosporium sp. under glyphosate and glufosinate. The fungi genus Trichoderma was found under mechanical weeding and under glyphosate and is normally occurring in all soil types is representing the most commonly cultivated fungi also forming avirulent symbioses with plants (Harman et al. 2004). The mold Striatibotrys sp. (also called Stachybotrys sp.) produces the stachybotrys mycosis pathogen (Summerbell et al. 1989) and was found under glyphosate and flazasulfuron.

This is among the first field studies investigating the effects of three commonly used herbicides and mechanical weeding on soil microorganisms in vineyards. As all treatments left weed material on ground, the finding that certain herbicides stimulated or suppressed certain fungi suggests that herbicide-specific active ingredients, adjuvants or nutrients might be responsible for this effect. Although the study vineyard was evenly treated with other pesticides according to good viticultural practice, potential interactions with specific herbicides are likely. It is important to note that the findings need to be interpreted with caution as the study was conducted during one field season in one experimental vineyard. Overall, we know very little about the role of microorganisms in vineyard soils and their consequences for health, yield and quality of the grapevine (Belda et al. 2017). However, the microbial terroir concept suggests important association between microorganisms in different compartments of the vineyard ecosystem and wine characteristics (Bokulich et al. 2014; Gilbert et al. 2014; Miura et al. 2017). Clearly, more long-term studies are needed to further elucidate non-target effects of pesticides used in vineyard management.

Acknowledgements Open access funding provided by University of Natural Resources and Life Sciences Vienna (BOKU). We are grateful to the technical staff of the Federal College and Research Center for 
Viticulture and Pomology for maintaining the experimental vineyard during the course of this experiment.

Open Access This article is distributed under the terms of the Creative Commons Attribution 4.0 International License (http://creativeco mmons.org/licenses/by/4.0/), which permits unrestricted use, distribution, and reproduction in any medium, provided you give appropriate credit to the original author(s) and the source, provide a link to the Creative Commons license, and indicate if changes were made.

\section{References}

Abujabhah IS, Doyle RB, Bound SA, Bowman JP (2017) Assessment of bacterial community composition, methanotrophic and nitrogen-cycling bacteria in three soils with different biochar application rates. J Soils Sediment 18:148-158

Andreazza R, Okeke BC, Pieniz S, Bortolon L, Lambais MR, Camargo FAO (2012) Effects of stimulation of copper bioleaching on microbial community in vineyard soil and copper mining waste. Biol Trace Elem Res 146:124-133

Angly FE, Dennis PG, Skarshewski A, Vanwonterghem I, Hugenholtz P, Tyson GW (2014) CopyRighter: a rapid tool for improving the accuracy of microbial community profiles through lineage-specific gene copy number correction. Microbiome 2:11

Barros MB, de Almeida Paes R, Schubach AO (2011) Sporothrix schenckii and sporotrichosis. Clin Microbiol Rev 24:633-654

Bartnicki-Garcia S (1968) Cell wall chemistry, morphogenesis, and taxonomy of fungi. Ann Rev Microbiol 22:87-108

Bauer K, Regner F, Friedrich B (2017) Weinbau. Cadmos Verlag, Munich

Belda I, Zarraonaindia I, Perisin M, Palacios A, Acedo A (2017) From vineyard soil to wine fermentation: microbiome approximations to explain the "terroir" concept. Front Microbiol 8:821

Bokulich NA, Thorngate JH, Richardson PM, Mills DA (2014) Microbial biogeography of wine grapes is conditioned by cultivar, vintage, and climate. Proc Natl Acad Sci USA 111:E139-E148

Campisano A, Antonielli L, Pancher M, Yousaf S, Pindo M, Pertot I (2014) Bacterial endophytic communities in the grapevine depend on pest management. PLoS ONE 9:e112763

Cannon P, Kirk P (2007) Fungal families of the world. CAB International, Wallingford

Carson JK, Rooney D, Gleeson DB, Clipson N (2007) Altering the mineral composition of soil causes a shift in microbial community structure. FEMS Microbiol Ecol 61:414-423

Chaparro JM, Sheflin AM, Manter DK, Vivanco JM (2012) Manipulating the soil microbiome to increase soil health and plant fertility. Biol Fertil Soils 48:489-499

Chou M-Y, Vanden Heuvel J, Bell TH, Panke-Buisse K, Kao-Kniffin J (2018) Vineyard under-vine floor management alters soil microbial composition, while the fruit microbiome shows no corresponding shifts. Sci Rep 8:11039

Cock PJA, Fields CJ, Goto N, Heuer ML, Rice PM (2010) The Sanger FASTQ file format for sequences with quality scores, and the Solexa/Illumina FASTQ variants. Nucleic Acids Res 38:1767-1771

Corneo PE, Pellegrini A, Cappellin L, Gessler C, Pertot I (2013) Weeds influence soil bacterial and fungal communities. Plant Soil 373:107-123

de Meyer EM, de Beer ZW, Summerbell RC, Moharram AM, de Hoog GS, Vismer HF, Wingfield MJ (2008) Taxonomy and phylogeny of new wood- and soil-inhabiting Sporothrix species in the Ophiostoma stenoceras-Sporothrix schenckii complex. Mycologia 100:647-661
Deacon JW (2005) Fungal biology, 4th edn. Blackwell, Oxford

Domsch KH, Gams W, Anderson TH (2007) Compendium of soil fungi, 2 edn. IHW-Verlag, Eching

Dong JY, Zhao ZX, Cai L, Liu SQ, Zhang HR, Duan M, Zhang KQ (2004) Nematicidal effect of freshwater fungal cultures against the pine-wood nematode Bursaphelenchus xylophilu. Fungal Divers 15:125-135

Duke SO (2014) Biotechnology: herbicide resistant crops. In: Neal $\mathrm{K}$, Van Alfen (eds) Encyclopedia of agriculture and food systems, 2nd edn. Elsevier, Amsterdam

Eren AM, Morrison HG, Lescault PJ, Reveillaud J, Vineis JH, Sogin ML (2015) Minimum entropy decomposition: unsupervised oligotyping for sensitive partitioning of high-throughput marker gene sequences. ISME J 9:968-979

Felšöciová S, Rybárik L, Tančinová D, Mašková Z, Kačániová M (2015) Microfungi and mycotoxins of grapes from Eastern Slovak wine region. J Microbiol Biotechnol Food Sci 04:12-15

Fernández-Calviño D, Martín A, Arias-Estévez M, Bååth E, DíazRaviña M (2010) Microbial community structure of vineyard soils with different $\mathrm{pH}$ and copper content. Appl Soil Ecol 46:276-282

Fincher RM, Fisher JF, Lovell RD, Newman CL, Espinel-Ingroff A, Shadomy HJ (1991) Infection due to the fungus Acremonium (cephalosporium). Medicine 70:398-409

Fu Y, Li X, Zheng S, Du J, Liang A (2015) Classification and identification of bacteria in the soil treated by AcMNPV using highthroughput sequencing technique. Biotechnol Bioprocess Eng 20:931-936

Fukushima K, Arai T, Mori Y, Tsuboi M, Suzuki M (1983a) Studies on peptide antibiotics, leucinostatins. I. Separation, physicochemical properties and biological activities of leucinostatins A and B. J Antibiot 36:1606-1612

Fukushima K, Arai T, Mori Y, Tsuboi M, Suzuki M (1983b) Studies on peptide antibiotics, leucinostatins. II. The structures of leucinostatins A and B. J Antibiot 36:1613-1630

Gilbert JA, van der Lelie D, Zarraonaindia I (2014) Microbial terroir for wine grapes. PNAS 111:5-6

Harman GE, Howell CR, Viterbo A, Chet I, Lorito M (2004) Trichoderma species-opportunistic, avirulent plant symbionts. Nat Rev Microbiol 2:43

Hendgen M, Hoppe B, Döring J, Friedel M, Kauer R, Frisch M, Dahl A, Kellner H (2018) Effects of different management regimes on microbial biodiversity in vineyard soils. Sci Rep 8:9393

Hiernickel C, Wiegand C, Schliemann S, Seyfarth F, Jung K, Elsner P, Hipler UC (2016) Trichophyton species of Arthroderma benhamiae: clinical therapeutic aspects of a new pathogen in dermatology. Der Hautarzt; Zeitschrift für Dermatologie, Venerologie und verwandte Gebiete 67:706-711

Hoog GS, Guarro J, Gené J, Figueras MJ (2000) Atlas of clinical fungi, 2 edn. Centraalbureau voor Schimmelcultures, Baarn

Hughes S (1958) Colletotrichum coccodes (Wallr.). Can. J. Bot. $36: 754$

Keller M (2015) The science of grapevines, 2 edn. Elsevier, Oxford

Kilama P, Duois T, Coyne D, Niere B, Gold CS, Adipala E (2007) Antagonism of Paecilomyces spp. isolated from banana (Musa spp.) roots and rhizosphere against Radopholus similis. Nematropica 37:215-225

Kopčáková A, Legáth J, Pristaš P, Javorský P (2016) Already a shortterm soils exposure to the field-rate glufosinate concentration significantly influences soil bacterial communities. Soil Water Res 10:271-277

Li J, Yang JK, Huang XW, Zhang KQ (2006) Purification and characterization of an extracellular protease from Clonostachys rosea and its potential as a pathogenic factor. Process Biochem 41:925-929 
Likar M, Stres B, Rusjan D, Potisek M, Regvar M (2017) Ecological and conventional viticulture gives rise to distinct fungal and bacterial microbial communities in vineyard soils. Appl Soil Ecol 113:86-95

Magné C, Saladin G, Clément C (2006) Transient effect of the herbicide flazasulfuron on carbohydrate physiology in Vitis vinifera $\mathrm{L}$. Chemosphere 62:650-657

Magyar D, Frenguelli G, Bricchi E, Tedeschini E, Csontos P, Li D-W, Bobvos J (2009) The biodiversity of air spora in an Italian vineyard. Aerobiologia 25:99-109

Mari M, Cembali T, Casalini L, Pratella GC (2000) Mucor species in orchard soil-population dynamics and pathogenicity on pear fruit. Eur J Plant Pathol 106:449-454

Marilley L, Aragno M (1999) Phylogenetic diversity of bacterial communities differing in degree of proximity of Lolium perenne and Trifolium repens roots. Appl Soil Ecol 13:127-136

Meyer-Dombard DR, Amend JP (2014) Geochemistry and microbial ecology in alkaline hot springs of Ambitle Island, Papua New Guinea. Extremophiles 18:763-778

Mezzasalma V, Sandionigi A, Bruni I, Bruno A, Lovicu G, Casiraghi M, Labra M (2017) Grape microbiome as a reliable and persistent signature of field origin and environmental conditions in Cannonau wine production. PLoS ONE 12:20

Miura T, Sánchez R, Castañeda LE, Godoy K, Barbosa O (2017) Is microbial terroir related to geographic distance between vineyards? Environ Microbiol Rep 9:742-749

Morandi MAB, Maffia LA, Mizubuti ESG, Alfenas AC, Barbosa JG (2003) Suppression of Botrytis cinerea sporulation by Clonostachys rosea on rose debris: a valuable component in Botrytis blight management in commercial greenhouses. Biol Control 26:311-317

Morgan HH, du Toit M, Setati ME (2017) The grapevine and wine microbiome: insights from high-throughput amplicon sequencing. Front Microbiol 8:820

Mücke W, Lemmen C (2005) Schimmelpilze: Vorkommen, Gesundheitsgefahren, Schutzmaßnahmen, 3 edn. Ecomed, Landsberg am Lech

Newman MM, Hoilett N, Lorenz N, Dick RP, Liles MR, Ramsier C, Kloepper JW (2016) Glyphosate effects on soil rhizosphereassociated bacterial communities. Sci Total Environ 543:155-160

ÖPUL (2007) Erosionsschutzprogramm, https://www.ama.at/getat tachment/0543decc-1af6-48ac-94c0-3a6048dfebf1/MEB_Oepul 2015_Erosionsschutz_Obst-Wein-Hopfen_3-0.pdf. Accessed 18 Sept 2018

Pancher M, Ceol M, Corneo PE, Longa CM, Yousaf S, Pertot I, Campisano A (2012) Fungal endophytic communities in grapevines (Vitis vinifera L.) respond to crop management. Appl Environ Microbiol 78:4308-4317

Paoletti MG, Sommaggio D, Favretto MR, Petruzzelli G, Pezzarossa B, Barbafieri M (1998) Earthworms as useful bioindicators of agroecosystem sustainability in orchards and vineyards with different inputs. Appl Soil Ecol 10:137-150

Pinto C, Gomes AC (2016) Vitis vinifera microbiome: from basic research to technological development. BioControl 61:243-256

Poblet M, Rozès N, Guillamón JM, Mas A (2000) Identification of acetic acid bacteria by restriction fragment length polymorphism analysis of a PCR-amplified fragment of the gene coding for $16 \mathrm{~S}$ rRNA. Lett Appl Microbiol 31:63-67

Rillig MC (2004) Arbuscular mycorrhizae and terrestrial ecosystem processes. Ecol Lett 7:740-754

Rodriguez R, Redman R (2008) More than 400 million years of evolution and some plants still can't make it on their own: plant stress tolerance via fungal symbiosis. J Exp Bot 59:1109-1114

Salt GA (1977) The incidence of root-surface fungi on naturally regenerated Picea sitchensis seedlings in southeast Alaska. Forestry 50:113-115
Samad A, Trognitz F, Compant S, Antonielli L, Sessitsch A (2017) Shared and host-specific microbiome diversity and functioning of grapevine and accompanying weed plants. Environ Microbiol 19:1407-1424

Steenwerth KL, Drenovsky RE, Lambert JJ, Kluepfel DA, Scow KM, Smart DR (2008) Soil morphology, depth and grapevine root frequency influence microbial communities in a Pinot noir vineyard. Soil Biol Biochem 40:1330-1340

Steinrücken HC, Amrhein N (1980) The herbicide glyphosate is a potent inhibitor of 5-enolpyruvylshikimic acid-3-phosphate synthase. Biochem Biophys Res Commun 94:1207-1212

Summerbell RC, Krajden S, Kane J (1989) Potted plants in hospitals as reservoirs of pathogenic fungi. Mycopathologia 106:13-22

Tan SC, Tan TK, Wong SM, Khor E (1996) The chitosan yield of Zygomycetes at their optimum harvesting time. Carbohydr Polym 30:239-242

van Hoesel W, Tiefenbacher A, König N, Dorn VM, Hagenguth JF, Prah Ua, Widhalm T, Wiklicky V, Koller R, Bonkowski M, Lagerlöf J, Ratzenböck A, Zaller JG (2017) Single and combined effects of pesticide seed dressings and herbicides on earthworms, soil microorganisms, and litter decomposition. Front Plant Sci 8:215. https://doi.org/10.3389/fpls.2017.00215

Vasquez-del-Mercado E, Arenas R, Padilla-Desgarenes C (2012) Sporotrichosis. Clin Dermatol 30:437-443

Wang S, Hou W, Dong H, Jiang H, Huang L, Wu G, Zhang C, Song Z, Zhang Y, Ren H, Zhang J, Zhang L (2013) Control of temperature on microbial community structure in hot springs of the tibetan plateau. PLoS ONE 8:e62901

Webster J (2012) Introduction to fungi, 3rd edn. Cambridge University Press, Cambridge

Wei Y-j, Wu Y, Yan Y-z, Zou W, Xue J, Ma W-r, Wang W, Tian G, Wang L-y (2018) High-throughput sequencing of microbial community diversity in soil, grapes, leaves, grape juice and wine of grapevine from China. PLoS ONE 13:e0193097

Weidenbörner M (1998) Schimmelpilzkatalog_Lebensmittel. Cena Verlag, Meckenheim

White TJ, Bruns T, Lee S, Taylor J (1990) Amplification and direct sequencing of fungal ribosomal RNA genes for phylogenetics. In: PCR protocols. Academic Press, San Diego, pp 315-322

Wilkinson V, Lucas RL (1969) Effects of herbicides on the growth of soil fungi. New Phytol 68:709-719

Zaller JG, Heigl F, Ruess L, Grabmaier A (2014) Glyphosate herbicide affects belowground interactions between earthworms and symbiotic mycorrhizal fungi in a model ecosystem. Sci Rep 4:5634

Zaller JG, Cantelmo C, Santos GD, Muther S, Gruber E, Pallua P, Mandl K, Friedrich B, Hofstetter I, Schmuckenschlager B, Faber F (2018) Herbicides in vineyards reduce grapevine root mycorrhization and alter soil microorganisms and the nutrient composition in grapevine roots, leaves, xylem sap and grape juice. Environ Sci Pollut Res 25:23215-23226

Zarraonaindia I, Weisenhorn MOS, West P, Hempton-Marcell K, Lax J, Bokulich S, Mills NA, Martin DA, Taghavi G, Van der Lelie S, Gilbert D JA (2015) The soil microbiome influences grapevineassociated mecrobiota. Mbio 6:e02527-e02514

Zehetner F, Djukic I, Hofmann R, Kühnen L, Rampazzo-Todorovic G, Gerzabek MH, Soja G (2015) Soil organic carbon and microbial communities respond to vineyard management. Soil Use Manage 31:528-533

Zhang L, Yang J, Niu Q, Zhao X, Ye F, Liang L, Zhang KQ (2008) Investigation on the infection mechanism of the fungus Clonostachys rosea against nematodes using the green fluorescent protein. Appl Microbiol Biotechnol 78:983-990

Zhao ML, Huang JS, Mo MH, Zhang KQ (2005) A potential virulence factor involved in fungal pathogenicity: serine-like protease activity of nematophagous fungus Clonostachys rosea. Fungal Divers 19:217-234 